\title{
Controls on Capital Inflows and External Shocks
}

\author{
Antonio C. David ${ }^{1}$ \\ adavid2@worldbank.org
}

\begin{abstract}
In this paper we attempt to analyze whether price-based controls on capital inflows are successful in insulating economies against external shocks. We present results from VAR models that indicate that Chile and Colombia, countries that adopted controls on capital inflows, seem to have been relatively well insulated against external disturbances. Subsequently, we use the ARDL approach to co-integration in order to isolate the effects of the capital controls on the pass-through of external disturbances to domestic interest rates in those economies. We conclude that there is evidence that the capital controls allowed for greater policy autonomy.
\end{abstract}

JEL Classification: E60, F33, F34, O16, 054.

Keywords: Capital Flows, Capital Controls, Developing Countries.

World Bank Policy Research Working Paper 4176, March 2007

The Policy Research Working Paper Series disseminates the findings of work in progress to encourage the exchange of ideas about development issues. An objective of the series is to get the findings out quickly, even if the presentations are less than fully polished. The papers carry the names of the authors and should be cited accordingly. The findings, interpretations, and conclusions expressed in this paper are entirely those of the authors. They do not necessarily represent the view of the World Bank, its Executive Directors, or the countries they represent. Policy Research Working Papers are available online at http://econ.worldbank.org.

\footnotetext{
${ }^{1}$ I would like to thank Edouard Challe, Carmen Li, Chris Meissner, Gabriel Palma, John Eatwell and participants at the Annual MMF Research Group conference in September 2005 for comments. I also would like to thank Francisco Gallego, Hernan Rincon and Andre Loureiro for help with data.
} 


\section{Introduction}

It is usually recognized by analysts that Chile and Colombia were spared from the financial turmoil that originated in Mexico by the end of 1994; nevertheless, it is also argued that those two countries suffered difficulties following the Asian and Russian debacle at the end of that decade. Contrary to a large number of countries in the region, Chile and Colombia adopted price-based capital account regulations in order to manage their integration to international financial markets and avoid some of the deleterious side effects of liberalization such as excessive real exchange rate appreciations. The effectiveness of these regulations has been subject to heated debate (see David, 2005 for a recent survey). In this paper, we will attempt to analyze whether the controls on capital inflows adopted by the two countries were successful in reducing the vulnerability of those economies to external shocks.

This paper is divided into three sections. Firstly, we will review the channels through which the reserve requirements on capital inflows could possibly affect the transmission of international shocks to the domestic economy. Subsequently, we will present results from vector autoregressive models in order to assess the transmission of global financial shocks to the Chilean and Colombian economies. Finally, in the third section, we will use the ARDL approach to co-integration in order to attempt to isolate the effects of the capital controls on the pass-through of external disturbances to domestic interest rates. 


\section{The Unremunerated Reserve Requirement and International Shocks}

Asymmetric $^{\mathrm{i}}$ taxes, such as the unremunerated reserve requirements adopted by Chile and Colombia, could affect the transmission of international shocks to the domestic economy through several channels, including correcting market failures due to moral hazard (see for instance Dooley \& Walsh, 2000). They could act as "speed bumps" in periods of excessive liquidity and expansionary pressures, which are a characteristic of the upswing of financial cycles (Palma, 2000 and 2003). During this credit expansion phase, there is an increase in credit risk because the quality of financial intermediaries' portfolios decreases, leading to an increase in nonperforming loans.

This is aggravated by the fact that financial market agents frequently have inappropriate responses to changes in risk over the economic cycle, such that risks are underestimated during booms and overestimated during recessions. In the presence of these dynamics, the adoption of restrictions on capital inflows in a countercyclical manner in order to mitigate the expansionary effects associated with surges in capital inflows could be an appropriate policy response in capital importing countries with the objective of reducing economic volatility (Palma, 2003).

In addition, the currency mismatch strand of the financial crises literature argues that if a substantial amount of debt is denominated in foreign currency due to “Original Sin”ii, a country could become vulnerable to self-fulfilling crises (Aghion et al., 2000). By taxing capital inflows it is possible to restrict the level of external indebtedness and limit the negative real effects of devaluations due to the exposure of domestic firms' balance sheets. In fact, benefits arise because the decision by an individual firm to borrow in foreign currency imposes costs on the rest of the economy that are internalized by the tax on inflows.

Furthermore, the maturity structure of external debt seems to matter for the occurrence and severity of currency collapses (Carlson and Hernandez, 2002). This fact has been addressed theoretically by the maturity mismatch literature (Rodrik \& Velasco, 1999). This type of model emphasizes that in the presence of market failures, borrowers would not consider the effects of the stock of short-term debt on contractual interest rates and would choose the privately less costly option of taking short-term rather than long-term debt. Hence, reserve requirements on short-term capital inflows could play a role in reducing the likelihood of liquidity problems by mitigating the externality associated with short-term debt. 
Moreover, the unremunerated reserve requirements (URR) might be able to reduce the vulnerability of a country to external shocks through prevention of real exchange rate overvaluation. Dornbusch, Goldfajn and Valdes (1995) show that an overvalued real exchange rate is a fairly good predictor of future currency crises; therefore the impact of the reserve requirements on the real exchange rate seems to be of considerable importance.

There is a vast literature that focuses on specific transmission channels of crises from one country/region to another and emphasizes mostly trade and financial links as the main carriers of spill-over effects associated with financial stress (see Dungey et al., 2003 for a survey). The spread of crises through trade links can take place via competitive devaluations or simply by the reduction in demand for exports due to a weaker economic situation in the "ground zero" and other affected countries.

The role of financial links is slightly more complex. While some authors concentrate on common lender effects (a lender is affected by crisis in one country, faces liquidity problems such as margin calls and has to liquidate its assets elsewhere); others focus on "rebalancing effects" in the context of standard portfolio models, where investors pull away from risky assets (emerging markets) when faced with a large negative shock, i.e. an increase in volatility (Schinasi and Smith, 1999). The latter effect is akin to a simple increase in risk aversion by international players. Calvo and Mendoza (2000) emphasize the importance of information asymmetries and costs in acquiring information about specific markets, which encourage herd behavior by international investors as a major source of “contagion”. We could also consider a more general story, where in the presence of multiple equilibria, a crisis in one country can act as a sunspot and coordinate investors' expectations. In this case, the transmission of crises occurs purely because of changes in investor's beliefs.

What role could the URR play in addressing those transmission channels of crises? This type of controls on capital inflows is capable of mitigating problems related to liquidity risk by increasing the maturity structure of external debt. Hence it may reduce the exposure to sudden capital outflows associated with the "common lender”, “risk aversion”, “Calvo and Mendoza-style herd behavior” and other multiple equilibria stories. Nonetheless, the reserve requirements cannot affect trade links in a direct clear-cut way and therefore cannot prevent distress when trade is a major transmission channel of shocks. 
We should conclude this section by noting that controls on capital inflows may be ineffective against runs by domestic residents, which were particularly important in the Mexican and Brazilian crisis episodes (Frenkel \& Schmukler, 1996 and Goldfajn, 2000). Nevertheless, one has to note that by changing the maturity structure of external debt, the controls make runs more expensive and hence could play an indirect role in preventing them.

\section{Evidence from Vector Autoregressive Models}

Our objective in this section is to obtain some stylized facts about the response of domestic macroeconomic variables to external shocks, measured by the spread paid by emerging markets over U.S. instruments of the same maturity. For this purpose, we will use the global Emerging Markets Bond Index (EMBI) spreads constructed by J.P. Morgan. This index tracks the traded market for U.S. dollar denominated Brady and other similar bonds and is widely regarded as an appropriate measure of foreign investors' risk perceptions regarding emerging markets. We chose to use the EMBI rather than the commonly used EMBI+ spreads (which is a less restrictive index, including Eurobonds and other sovereign debt instruments) because of data availability as the latter series only starts in $1998^{\mathrm{iii}}$.

We will implement reduced-form models of the transmission of international shocks to macroeconomic variables using the vector autoregressive (VAR) methodology. Other authors such as Edwards (2000) and Edison and Reinhart (2001) have previously used this framework for similar purposes.

When specifying a reduced-form VAR model it is crucial to assess whether the variables included in the system are stationary or not for inference to be valid, since it is well known that testing hypotheses on coefficients of integrated variables requires non-standard asymptotic theory ${ }^{\text {iv }}$ (Canova, 1995). In our first model, we will use a foreign exchange market pressure index for Argentina, Chile, Colombia and Mexico as endogenous variables in the system.

We construct the pressure index following the empirical literature on currency crises in order to account for the fact that in periods of stress due to external shocks the burden of adjustment does not fall exclusively on interest rates, but it is also reflected in changes in international reserves and changes in the nominal exchange rate. Our index is a weighted average of changes in domestic interest rates; nominal 
exchange rates and the log of foreign reserves (see Eichengreen, Rose and Wyploz, 1996 for a similar index). Hence, the pressure index on foreign exchange markets for country $\mathrm{j}$ at time $\mathrm{t}$ is given by:

$$
e m p_{j t}=\left(\frac{1}{\sigma_{i}}\right) \Delta i_{t}+\left(\frac{1}{\sigma_{s}}\right) \Delta s_{t}-\left(\frac{1}{\sigma_{R}}\right) \Delta R_{t}
$$

We estimated the model from May 1991 to June 2001 and included the global EMBI spread and the pressure indexes, as constructed above for the different countries, as endogenous variables in our system. In addition, the junk bond spread (this variable has been used in the literature as a measure of international investor's risk appetite, see Mody \& Taylor, 2002) and the log of world oil price index (included to capture real shocks) were used as exogenous variables in the system. The data definitions and sources are described in Appendix B.

We chose a lag structure of 4 for this model, as there was a conflict between the different information criteria; the LM test does not detect serial correlation of the residuals for this specification. The unit root tests performed and reported in Appendix A showed that all the pressure indexes are stationary. Note also that both tests reject the null of a unit root for the EMBI spread, the junk bond spread and the world oil price series at the $5 \%$ level.

It is important to note that we decided not to include Brazil in our models due to the fact that the 1994 Real stabilization plan represents a significant structural break that would have reduced the sample size of the specifications (prior to 1994 this country was experiencing a turbulent period of high inflation). In addition, Brazil adopted controls on inflows of a quite different form (see David, 2007) and, therefore, neither constitutes an adequate "observation" of a country that imposed reserve requirements nor an appropriate “counterfactual” for our analysis.

The generalized impulse responses presented in Figure 1 demonstrate that the pressure indexes for Chile and Colombia do not respond significantly ${ }^{\mathrm{v}}$ to shocks to the EMBI spread nor do they respond significantly to shocks to the other countries' (Argentina and Mexico) pressure indexes. Nevertheless, the Argentinean and Mexican indexes do respond to EMBI shocks and Mexico is the country that presents the strongest response. It is also of interest to note that the Argentinean pressure index presents a statistically significant response to shocks in the Mexican pressure index indicating that financial "contagion” occurred between these two countries. 
The advantage of using generalised impulse responses when compared to standard Cholesky ones is that they do not depend on the ordering of the variables in the system. Generalized impulse responses compare the conditional expectation of a variable in the model, given a shock and the history of the model, to the conditional expectation of that variable given the historically observed information of the model (Koop, Pesaran \& Potter, 1996 for details).

Table 1 shows the variance decomposition for the VAR model estimated above. One should note that only a small percentage of the forecast errors in the Chilean and Colombian pressure indexes can be attributed to EMBI shocks. In fact, the figures are $0.07 \%$ and $1.17 \%$ for the first month for each country respectively. Nevertheless, when we look at the Argentinean and Mexican indexes for the same horizon, those figures become much larger (15.69\% and $40.26 \%$ respectively).

These results indicate that the unremunerated reserve requirements (combined with other capital account polices) might have helped to insulate the Chilean and Colombian economies from certain types of global external financial shocks, namely the ones captured by the EMBI spread. Evidently, at this stage, we cannot distinguish whether this difference is due to capital account policies, other macroeconomic policies, or simply the type of exchange rate regime adopted by the different countries. One also has to note that the precise role played by the capital controls in insulating those economies was not clarified in our empirical analysis so far.

In order to confirm the validity of our results we decided to estimate models for Chile and Colombia individually, including a wider selection of macroeconomic variables. The theoretical foundations of those VAR models are standard New Keynesian sticky-price models of the monetary transmission mechanism applied to small open economies, assuming that the domestic central bank responds (possibly with a lag due to information frictions and measurement limitations) to deviations of domestic inflation from the inflation target, to the output gap and to external conditions captured by the terms of trade, the real exchange rate gap, the sovereign risk premium and the EMBI spread.

First, we estimated a model of the Chilean economy using monthly data from January 1991 to December 2000, including as endogenous variables the EMBI spread, the output gap, the difference between inflation in the past 12 months (change in the consumer price index) and the inflation target, the exchange rate indexed deposit rate (this is the policy instrument), the Chilean sovereign risk premium (this variable was 
included to capture Chile's default risk as perceived by foreign investors) and the cyclical component of the real exchange rate. We also included as exogenous variables the logarithm of the Chilean terms of trade in order to capture real external shocks and the Junk Bond spread (for reasons already outlined). Since we assume that Chile is a small open economy, it is intuitive to think that no biases arise by considering those two variables as exogenous. The Akaike, Schwartz and H-Q information criteria suggested a model with two lags and there is no evidence of serial correlation for this specification, according to the LM test.

Once again variable sources and definitions are presented in the Appendix B. The unit root tests performed (Appendix A) show that the null of non-stationarity is rejected at the $5 \%$ level for the inflation, interest rate and country risk series. Nonstationarity is also rejected for the terms of trade series at the $10 \%$ level and for the output gap and real exchange rate series at the $1 \%$ level.

The generalized impulse responses are presented in Figure 2. One should note that the domestic exchange-rate-indexed deposit rate does not present a statistically significant response to shocks to the EMBI spread, whereas the real exchange only presents a marginally significant response between the second and fourth months. Therefore, the impact of EMBI shocks on the real exchange rate seems to be relatively short-lived and small. In addition, the domestic deposit rate also seems to be resilient to shocks to the Chilean sovereign risk premium and so does the real exchange rate.

These conclusions are confirmed by the variance decomposition analysis (see Table 2). Shocks to the EMBI spread are only responsible for a small part of the forecast errors in the real exchange rate and the domestic deposit rate. In the first period, the EMBI accounts for $1.13 \%$ of forecast errors in the interest rate and $1.17 \%$ in the real exchange rate, whereas in period 10 the figures are $4.79 \%$ and $10.43 \%$ respectively. Hence, it seems that interest rates were insulated against external shocks in Chile, whereas the real exchange rate is slightly more vulnerable.

To sum up, the URR and other capital account policies seem to have been capable of reducing the pass-through of external shocks to the Chilean economy, especially as far as deposit interest rates are concerned. Nonetheless, the capital account policies did not completely insulate Chile, as the real exchange rate was more vulnerable to shocks.

In addition, we estimated a similar model for the Colombian economy for the period from January 1993 to June 2002. We included as endogenous variables the 
EMBI spread, the output gap, the difference between the inflation rate and the annual inflation target set by the Central Bank, the 90-day real deposit rate, the Colombian sovereign risk premium and the cyclical component of the real exchange rate. We also included as exogenous variables the log of the world oil price index (this variable was included to capture real shocks, since we do not have a reliable series for the Colombian terms of trade that spans the whole period), the junk bond spread and a dummy variable that takes the value of zero before September 1999 and one thereafter, to account for the change in the exchange rate band.

The Akaike information criterion suggests a model with two lags and the LM test does not detect serial correlation for that specification. Unit root tests show that all the variables included are stationary, except for the country risk premium (Appendix A). We decided to estimate a model including this variable in levels to make the interpretation of the results more clear. McCallum (1993) argues that if the residuals of each equation in the system are stationary and there is no evidence of serial correlation, the model in levels can be correctly estimated. The unit root tests presented in Appendix A indeed show that the residuals of each equation in the system are stationary.

The impulse response functions obtained are reported in Figure 3. One can observe that the domestic interest rate presents a marginally significant response to EMBI shocks between periods 2 and 5. The real exchange rate also presents a marginally significant response to EMBI shocks from period two to four. Hence, it seems that both domestic interest rates and the real exchange rate were relatively insulated against external financial disturbances, as the effects of EMBI shocks were small (barely different from zero) and short-lived.

When shocks to the country risk premium are considered, it is possible to observe that according to this model, the domestic deposit rate only presented a marginally significant response to country risk shocks. Nonetheless, the country risk variable seems to have larger effects on the real exchange rate (the response of the real exchange rate to country risk shocks is significant until the forth month and the shock dies out after 6 months).

The variance decomposition analysis (see Table 3) shows that shocks to the EMBI spread explain $23.24 \%$ of the forecast errors in the Colombian sovereign risk after 2 months, but only $3.32 \%$ of errors in interest rates and $2.66 \%$ of errors in the real exchange rate. These results clarify the conclusions obtained from the impulse 
response functions. The Colombian country risk seems to co-move with global risk premia, whereas domestic interest rates and the real exchange rate are relatively insulated from those shocks. We may conclude that the capital account management policies were relatively successful in insulating the Colombian economy against global shocks (as measured by the EMBI spreads).

\section{Disentangling the Effects of the URR}

In this section, we will attempt to isolate the possible role of the reserve requirements on capital inflows as far as the pass-through of external shocks to domestic interest rates is concerned and confirm whether those capital account restrictions contributed towards a greater autonomy for domestic monetary policy. Indeed, following the results from previous sections, our main conjecture is that the URR did reduce the effect of foreign shocks on domestic rates even in the context of a crawling band exchange rate regime.

It is well known in the econometrics literature that interest rates frequently behave in ways close to unit roots in finite samples. Nonetheless, it seems counterintuitive that they would present unit roots as this would mean that some series could go to infinity and others reach negative values. Series that are quite persistent in this way can present the same estimation problems in standard models as regressions involving non-stationary variables. In addition, the application of standard cointegration analysis tools such as the Johansen procedure requires the classification of the variables included in the model into $\mathrm{I}(1)$ or $\mathrm{I}(0)$, which is difficult in this case.

We will estimate error correction models that circumvent that issue for the Chilean indexed policy interest rate and include the 90-day Libor interest rate (in real terms) and the tax equivalent of the reserve requirement as explanatory variables. Hence, we implemented a model describing the dynamics of the Chilean interest rate, which is given by:

$$
\Delta i_{t}=C+\sum_{i=1}^{n} \beta_{i} \Delta i_{t-i}+\sum_{j=1}^{m} \alpha_{j} \Delta i_{t-j}^{*}+\sum_{w=1}^{k} \delta_{w} \Delta U R R_{t-w}+\psi\left(i_{t-1}-\lambda_{1} i_{t-1}^{*}-\lambda_{2} U R R_{t-1}\right)
$$

This expression determines the first differences in the domestic interest rate as a function of past changes of the rate itself, past changes in the LIBOR rate $\left(i^{*}\right)$, changes in the URR and an error-correction term. 
As mentioned before, it is not possible to determine unambiguously whether the variables that would form the long run relationship are stationary or not. Therefore, we decided to adopt the autoregressive-distributed lag (ARDL) approach to co-integration proposed by Pesaran et al. (2001) that does not require the classification of variables into stationary and non-stationary. This approach consists of two stages.

First, a test for the existence of a long-run relation between the variables is implemented. It amounts to a simple F-test for the joint significance of the lagged levels of the variables in the error-correction model outlined above. This F-statistic has a non-standard distribution irrespective of whether the variables are $\mathrm{I}(0)$ or $\mathrm{I}(1)$ and the appropriate critical value bounds have been tabulated by Pesaran et al. in order to test for the null of no co-integration (i.e. coefficients are not significantly different for zero).

In fact, there are two sets of critical values: one assuming that all the variables in the model are I(0) and the other assuming that all the variables are I(1). This provides a band covering all possible classification of variables. If the computed Fstatistic falls outside the band, it is possible to reach a conclusion regarding the existence of a co-integration relationship. On the other hand, if the statistic falls inside the band the result of the inference is inconclusive and depends whether the variables are $\mathrm{I}(1)$ or $\mathrm{I}(0)$. The second stage of the analysis refers to estimating the coefficients for the long-run relationships and making inferences about their values.

We estimated models for the Chilean rate on lagged values of itself, lagged values of the LIBOR interest rate and lagged values of the tax equivalent of the reserve requirements ${ }^{\mathrm{vi}}$ for the period from January 1991 to December 2000 (six lags were used in all specifications) $)^{\mathrm{vii}}$. We experimented two basic different models: one with a dummy for the turbulent period following the Russian default in 1998, which represents a transition away from the use of controls on inflows and another model including a dummy for the change in the exchange rate regime in September 1999.

As argued by Pesaran et al. (2001), ARDL estimation is applicable even when the explanatory variables are endogenous, provided that the order of the model is large enough to account for contemporaneous correlations between errors in the data generating process. In our case, the foreign interest is evidently long-run forcing and our tests for a model including the URR as the endogenous variable fail to reject the 
null that the level variables do not enter significantly in the equation, which indicates that the URR can be treated as an exogenous variable $\mathrm{viii}^{\text {. }}$

The F-statistic for those models of Chilean interest rates are 11.834 and 4.947 respectively, whereas the critical bounds at the 5\% level, calculated by Pesaran et al. are 3.10 and 3.87 (the critical bounds at the 1\% level are 4.13 and 5.00). Hence, we can conclude that there exists a long run relationship between those variables for the period analyzed, irrespectively of their order of integration, as the test statistic exceeds the critical bounds.

We now proceed to the estimation of the ARDL model. The Akaike information criterion suggests a ARDL(2,0,4) model for the specification including the 1998 dummy. If we consider the long-run relationship between the variables, the estimated coefficients are (with p-values in brackets):

$$
i_{t}=\underset{[0.00]}{4.51}+\underset{[0.00]}{0.27 i_{t}^{*}}+\underset{[0.00]}{0.20 U R R_{t}}+\underset{[0.00]}{2.96 \text { Dummy } 1998}
$$

One should note that all the coefficients are highly significant (even at the 1\% level). The coefficient of the URR is positive indicating that the URR allowed for higher interest rates in the long-run than would have been the case in the absence of capital controls. An increase in the URR by one unit would lead to an increase in the interest rate of 0.2 percentage points.

Hence, the adoption of the URR mitigated part of the expansionary pressures due to high capital inflows and allowed for greater monetary policy autonomy. One also has to note that the coefficient for the foreign interest rate is only 0.27 , therefore indicating that the adjustment of local rates to changes in foreign rates is less than proportional, thus confirming the evidence of relative monetary independence.

The estimation results for the error-correction model outlined above are presented in Table 4. All regressors are statistically significant and the diagnostic statistics do not show any evidence of serial correlation of the residuals and the high R-squared (0.56) indicates a good fit.

One interesting feature of the results presented above concerns the coefficient for the error correction term, which is relatively small (-0.306). This implies that the half-life, calculated as $\ln (0.5) / \ln (1+$ error-correction coefficient) is of approximately 2 months. This suggests that the speed of adjustment of domestic interest rates to foreign ones is only moderate, hence indicating greater monetary policy independence in the Chilean case. Therefore, we can conclude that the evidence so far corroborates 
our previous inferences concerning the insulating properties of controls on capital inflows.

Subsequently, we also applied the ARDL approach to analyse the effects of the reserve requirements on Colombian 90-day deposit interest rates ${ }^{\text {ix }}$. We estimated a very similar model to the one outlined for Chile. The sample period goes from January 1991 to December 2000 and a dummy variable taking the value of 1 after September 1999, when the exchange rate band was abandoned was included in the regressions. The F-statistic for this model is 4.242, which lies outside the bounds at the $5 \%$ level, but lies inside the bounds at the $1 \%$ level, therefore yielding inconclusive results. Nonetheless, given the small sample size, significance at the $5 \%$ level is more than adequate.

Hence, we can be reasonably confident that a long run relationship between those variables exists, irrespective of the order of integration of the variables. In addition, the tests indicate that the URR can be treated, once again, as a long-run forcing variable (the F-statistic for the model with the URR as the dependent variable is 1.84 , which is below the bounds at the $5 \%$ level).

The Akaike information criterion suggests a ARDL $(4,1,6)$ model. The estimated coefficients for the long run relationship are (with p-values in brackets):

$$
i_{t}=\underset{[0.07]}{3.96}+\underset{[0.02]}{1.74} i_{t}^{*}+\underset{[0.08]}{0.11 U R R_{t}}-\underset{[0.06]}{5.08} \text { Dummy1999 }
$$

One should note that all the coefficients are significant at the $10 \%$ level and have the expected signs. The coefficient of the URR is positive permitting us to infer that the URR allowed for higher interest rates in the long-run. Nonetheless, the coefficient is smaller than in the Chilean case. An increase in the URR by one unit would lead to an increase in the domestic interest rate of 0.11 percentage points.

The coefficient for the foreign interest rate exceeds 1 , implying more than proportionate changes in domestic rate when the foreign rate changes. This is not very surprising for an emerging market and it's in line with the evidence towards overadjustment of interest rates in developing countries to shocks in foreign interest rates provided by Frankel et al. (2004).

The estimation results for the error-correction model are presented in Table 5. Most regressors are statistically significant at conventional levels and the diagnostic statistics do not show any evidence of serial correlation of the residuals. Once again, 
the relatively high R-squared indicates a good fit of the model (although the normality of the residuals is rejected at the $5 \%$ level, but not at the $1 \%$ level).

The coefficient for the error correction term is small (-0.145), which indicates that adjustment towards equilibrium occurs slowly. In fact the half-life for Colombian rates is approximately 4 months (twice the one of Chile). This suggests, once again, a degree of monetary autonomy. Therefore, the evidence seems to indicate that the controls on capital inflows adopted were capable of mitigating the impact of external shocks on the domestic economy for both the Chilean and Colombian cases.

\section{Conclusion}

Unremunerated reserve requirements have the potential to be an effective flexible instrument to balance macroeconomic disequilibria arising from surges in capital inflows, such as large current account deficits linked to an excessive real exchange rate appreciation. Furthermore, this type of capital controls could be instrumental for the application of countercyclical macroeconomic policies; since they allow for greater policy autonomy in the face of pro-cyclical capital flows, as confirmed by the evidence presented in this paper.

We conclude that, when a very specific type of financial shock is considered, namely shocks to the EMBI index, the Chilean and Colombian economies seem to have been relatively well insulated against external disturbances, when compared to other large Latin American countries. In addition, when we look at the two countries individually, we found that, in the case of Chile, global financial shocks did not affect domestic interest rates and only marginally affected the real exchange rate. The Colombian economy also seems to have been relatively well insulated against external disturbances, as EMBI shocks only marginally affected both interest rates and the real exchange rate. One has to bear in mind that the reserve requirements are not the only policy measures that could possibly have reduced the external vulnerability in those countries.

Furthermore, by disentangling the specific effects of the capital controls on domestic interest rates, we uncovered evidence that the reserve requirements allowed for greater policy autonomy and did reduce the pass-through of external disturbances to the economies considered. In fact, the effects of foreign interest rate shocks on domestic rates were reduced even in the context of a crawling band exchange rate 
regime. Despite the fact that controls on capital inflows have the potential to be beneficial in terms of reducing financial vulnerability, this does not mean that these policies were applied "optimally" by the two countries at all moments in time (see Ffrench-Davis \& Tapia, 2001). 


\section{REFERENCES}

Aghion, P., Bachetta, P., Banerjee, A. (2000) “A simple model of monetary policy and currency crises” European Economic Review, 44 728-738.

Bennett, H. \& Valdes, R. (2001) "Series de terminos de intercambio de frecuencia mensual para la economia chilena: 1965-1999.” Working Paper 96, May. Santiago: Central Bank of Chile.

Calvo, G.A. \& Mendoza, G. (2000) "Rational Contagion and the Globalization of Securities Markets” Journal-of-International-Economics; 51(1), June p. 79-113.

Canova, F. (1995) "Vector Autoregressive Models: Specification, Estimation, Inference, and Forecasting” in Pesaran,-M.-Hashem; Wickens,-Michael-R., eds. Handbook of applied econometrics. Volume 1. Macroeconomics. Handbooks in Economics. Oxford and Malden, Mass.: Blackwell, 73-138.

Carlson, M. \& Hernandez, L. (2002) "Determinants and Repercussions of the composition of capital inflows.” Board of Governors of the Federal Reserve System International Finance Discussion Papers 717, January. Washington:DC.

David, A.C. (2005) “Are Price-Based Capital Account Regulations Effective? Evidence from the Experiences of Brazil, Chile and Colombia in the 1990s.” Faculty of Economics, University of Cambridge, Ph.D., Dissertation.

David, A.C. (2007) "Revisiting Price-Based Capital Account Regulations in a Sophisticated Emerging Market” World Development, Forthcoming.

Dooley, M.P. \& Walsh, C. (2000) "Capital Controls and Crises: Theory and Experience” University of California Santa Cruz. mimeo.

Dornbusch, R., Goldfajn, I. \& Valdes, R. (1995) “Currency Crises and Collapses” Brookings-Papers-on-Economic-Activity; 0(2): 219-70

Dungey, M. et al. (2003) "Empirical Modelling of Contagion: A Review of Methodologies” CERF Working Paper Series n 8 University of Cambridge.

Edison, H. \& Reinhart, C.M. (2001) "Stopping hot money” Journal of Development Economics, vol.66, 533-553.

Edwards, S. (2000) “Contagion” World-Economy. July; 23(7): 873-900.

Eichengreen, B., Rose, A. \& Wyplosz, C. (1996) “Contagious Currency Crises” The Scandinavian Journal of Economics, vol. 98 (4).

Eichengreen, B. \& Hausmann, R, (1999) “Exchange Rates and Financial Fragility” in New Challenges for Monetary Policy, Federal Reserve Bank of Kansas City, Jackson Hole Conference proceedings, forthcoming. 
Ffrench-Davis, R. \& Tapia, H. (2001) “Three Varieties of Capital Surge Management in Chile” in Ffrench-Davis, R. (ed.) Financial Crises in Successful Emerging Economies Brookings Institution Press Washington, D.C.

Frankel, J. et al. (2004) "Global transmission of interest rates, monetary independence and currency regime” Journal of International Money and Finance 23, p. 701-733.

Frenkel, J. \& Schmukler, S. (1996) "Country Funds Discounts and the Mexican Crises of December 1994: Did local residents turn pessimistic before international investors?” Federal Reserve Board working paper, IFDP 1996-563, September.

Gallego, F. Et al. (2002) “Capital Controls in Chile: Were they Effective?” in Hernandez, L. \& Schmidt-Hebbel eds. Banking, Financial Integration and International Crises. Santiago de Chile: Central Bank of Chile.

Goldfajn, I. (2000) “The Swings in Capital Flows and the Brazilian Crisis” Pontificia Universidade Catolica do Rio de Janeiro, mimeo.

Koop, G., Pesaran, M.H., Potter,S (1996) “Impulse Response Analysis in Nonlinear Multivariate Models” Journal-of-Econometrics. September 74(1): 119-47.

Mody, A. \& Taylor, M.P. (2002) "International Capital Crunches: The time-varying Role of Informational Asymmetries” IMF Working Paper 43 February, Washington: DC.

Palma, J.G. (2000) "The Three Routes to Financial Crises: the need for Capital Controls” University of Cambridge, mimeo.

Palma, J.G. (2003) “Notes on Capital Flows to Developing Countries” University of Cambridge, mimeo.

Pesaran, H. et al. (2001) "Bounds Testing Approach to the Analysis of Level Relationships” Journal of Applied Econometrics 16: 289-326.

Rincon, H. \& Villar, L. (2000) "The Colombian Economy in the1990s: Capital Flows and Foreign Exchange Regimes” Borradores de Economia ${ }^{0} 149$ Banco de la Republica. Bogota: Colombia.

Rodrik, D. \& Velasco, A. (1999) “Short-Term Capital Flows” NBER Working Paper 7364 Cambridge:MA.

Schinasi, G.J. \& Smith, R.T. (1999) "Portfolio Diversification, Leverage and Financial Contagion”. IMF Working Paper 99/136.

Sims, Stock \& Watson (1990) "Inference in Linear Time Series Models with Some Unit Roots” Econometrica-. January; 58(1): 113-44. 


\section{Figure 1}

Response to Generalized One S.D. Innovations \pm 2 S.E.
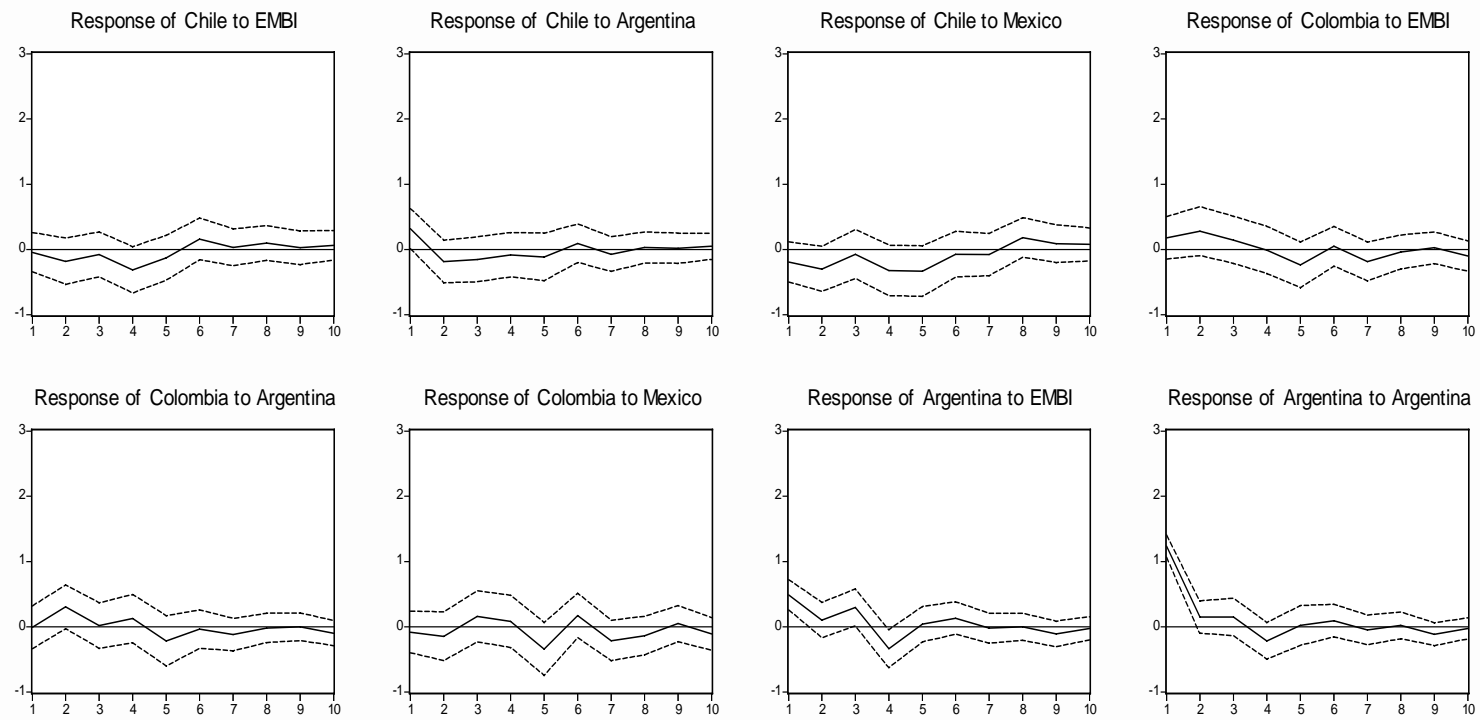

Response of Argentina to Argentina
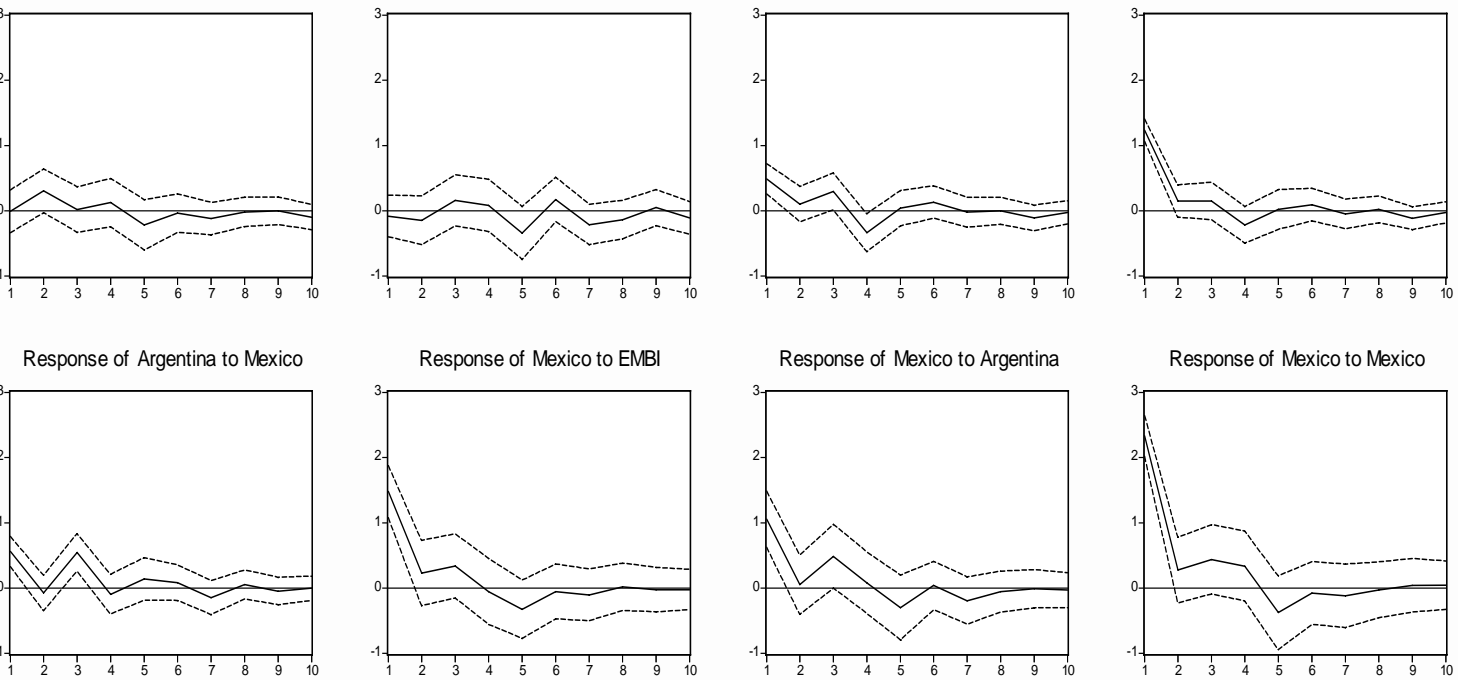

Response of Mexico to Mexico

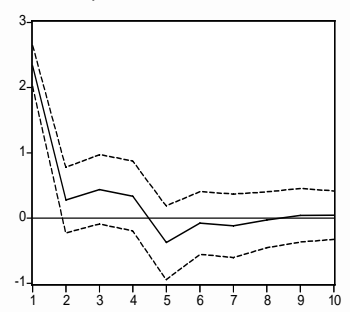


Figure 2

Response to Generalized One S.D. Innovations \pm 2 S.E.
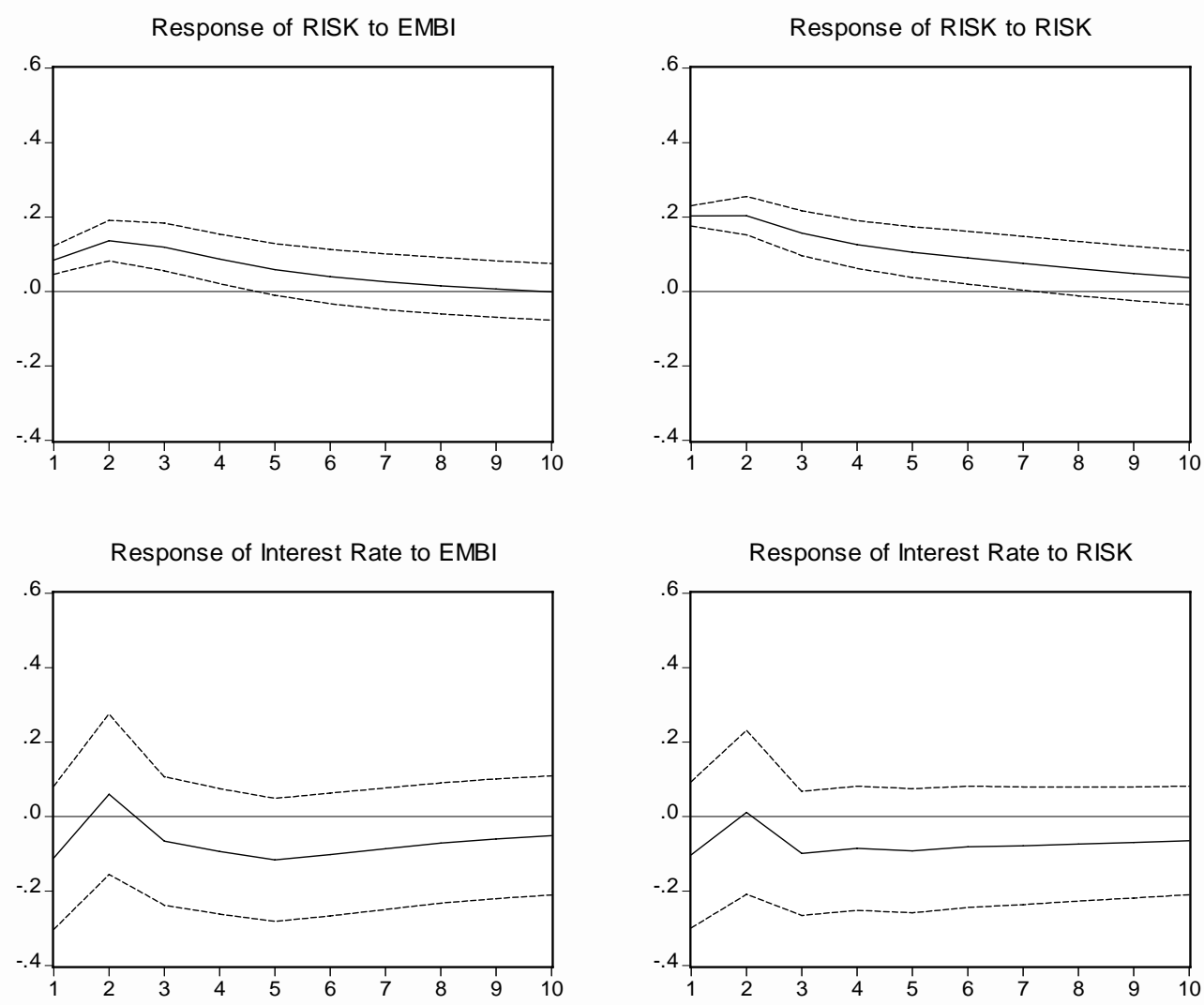

Response of Real Exchange Rate to EMBI

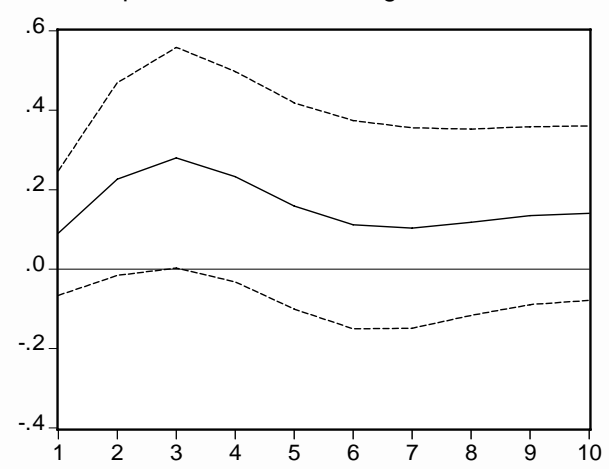

Response of Real Exchange Rate to RISK

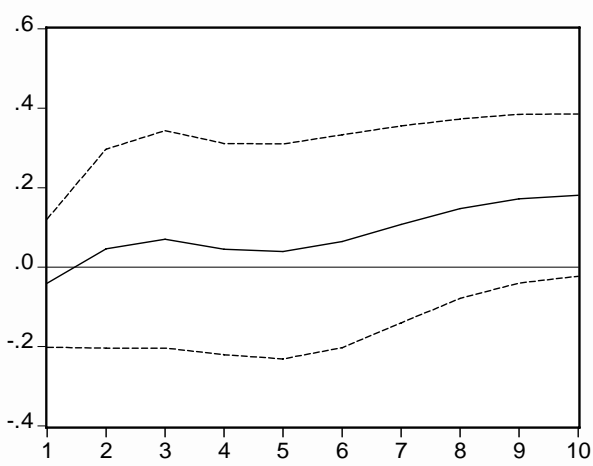




\section{Figure 3}

Response to Generalized One S.D. Innovations \pm 2 S.E.
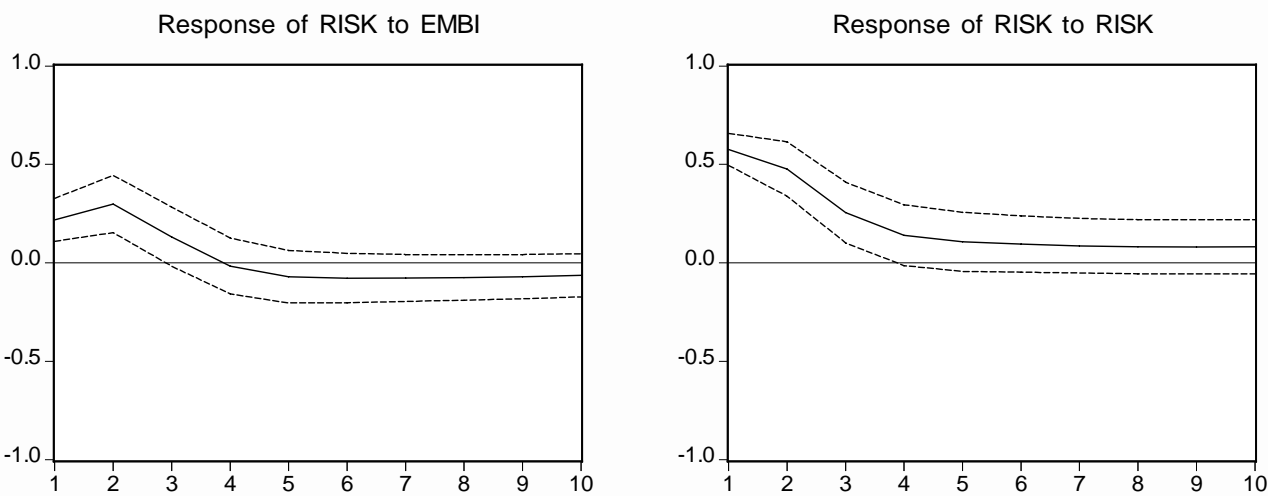

Response of Interest Rate to EMBI

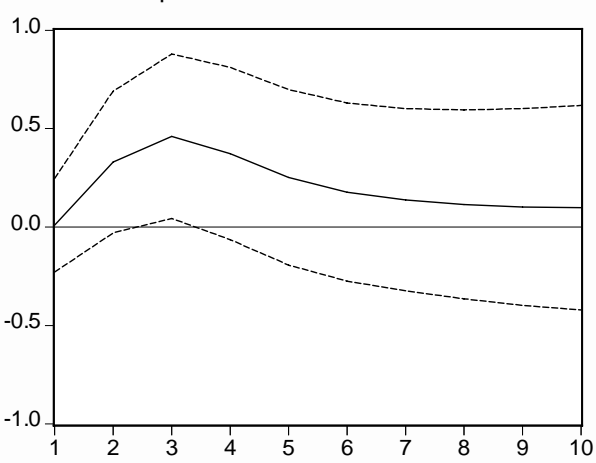

Response of Interest Rate to RISK

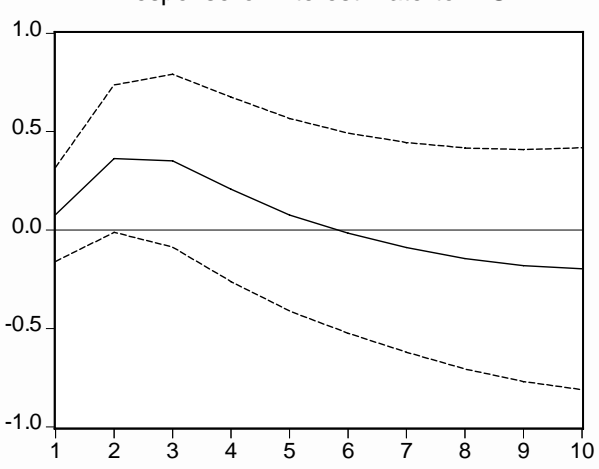

Response of Real Exchange Rate to EMBI

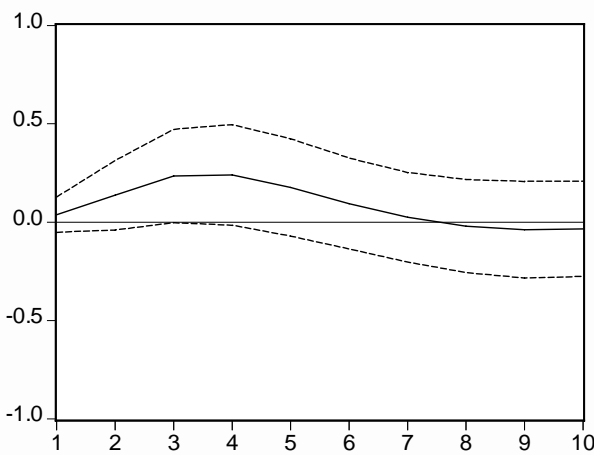

Response of Real Exchange Rate to RISK

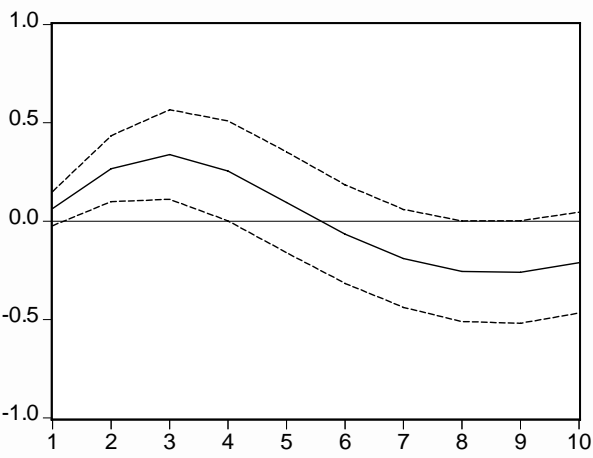


Table 1

Variance Decompositions

Percentage of Variance Associated with EMBI Shocks

\begin{tabular}{ccccc}
\hline Horizon & $\begin{array}{c}\text { Chilean Pressure } \\
\text { Index }\end{array}$ & $\begin{array}{c}\text { Colombian } \\
\text { Index }\end{array}$ & $\begin{array}{c}\text { Argentinean } \\
\text { Index }\end{array}$ & $\begin{array}{c}\text { Mexican } \\
\text { Index }\end{array}$ \\
\hline 1 & 0.07 & 1.17 & 15.69 & 40.26 \\
2 & 1.23 & 3.25 & 15.54 & 39.50 \\
5 & 4.49 & 5.11 & 20.12 & 35.98 \\
10 & 5.29 & 6.18 & 20.25 & 34.87 \\
\hline
\end{tabular}

Table 2

Variance Decompositions

Percentage of Variance Associated with EMBI Shocks

\begin{tabular}{cccc}
\hline Horizon & $\begin{array}{c}\text { Chilean Interest } \\
\text { Rate }\end{array}$ & $\begin{array}{c}\text { Chilean Country } \\
\text { Risk }\end{array}$ & $\begin{array}{c}\text { Chilean Real } \\
\text { Exchange Rate }\end{array}$ \\
\hline 1 & 1.13 & 17.28 & 1.17 \\
2 & 1.37 & 29.54 & 3.67 \\
5 & 3.01 & 33.69 & 8.87 \\
10 & 4.79 & 28.83 & 10.43 \\
\hline
\end{tabular}

Table 3

Variance Decompositions

Percentage of Variance Associated with EMBI Shocks

\begin{tabular}{cccc}
\hline Horizon & $\begin{array}{c}\text { Colombia } \\
\text { Interest Rate }\end{array}$ & $\begin{array}{c}\text { Colombia } \\
\text { Country Risk }\end{array}$ & $\begin{array}{c}\text { Colombia Real } \\
\text { Exchange Rate }\end{array}$ \\
\hline 1 & 0.00 & 14.31 & 0.70 \\
2 & 3.32 & 23.24 & 2.66 \\
5 & 7.19 & 20.43 & 7.83 \\
10 & 4.80 & 20.12 & 5.81 \\
\hline
\end{tabular}


Table 4

Error-Correction Model for the Chilean Interest Rate (1991-2000)

\begin{tabular}{|c|c|c|c|c|}
\hline Variable & $\begin{array}{c}\text { Coefficient } \\
\text { [P-values] }\end{array}$ & R-squared & Q-Statistic at lag 3 & Normality \\
\hline $\mathbf{C}$ & $\begin{array}{l}1.379 \\
{[0.00]}\end{array}$ & 0.560 & $\begin{array}{l}2.507 \\
{[0.43]}\end{array}$ & $\begin{array}{c}71.18 \\
{[0.00]}\end{array}$ \\
\hline$\Delta i_{t-1}$ & $\begin{array}{l}0.439 \\
{[0.00]}\end{array}$ & & & \\
\hline$\Delta i_{t}^{*}$ & $\begin{array}{c}0.083 \\
{[0.00]}\end{array}$ & & & \\
\hline$\Delta U R R_{t-1}$ & $\begin{array}{c}-0.075 \\
{[0.01]}\end{array}$ & & & \\
\hline$\Delta U R R_{t-2}$ & $\begin{array}{c}0.163 \\
{[0.00]}\end{array}$ & & & \\
\hline$\Delta U R R_{t-3}$ & $\begin{array}{l}-0.053 \\
{[0.10]}\end{array}$ & & & \\
\hline Error-Correction-Term & $\begin{array}{l}-0.306 \\
{[0.00]}\end{array}$ & & & \\
\hline
\end{tabular}

Q-statistic refers to the test for serial correlation of the residuals of the model. Normality is the Jarque-Bera test for the normality of the residuals in the regression. P-values for all the test statistics are presented in brackets.

Table 5

Error-Correction Model for the Colombian Interest Rate (1991-2000)

\begin{tabular}{|c|c|c|c|c|}
\hline Variable & $\begin{array}{l}\text { Coefficient } \\
\text { [P-values] }\end{array}$ & R-squared & Q-Statistic at lag 3 & Normality \\
\hline $\mathbf{C}$ & $\begin{array}{c}0.576 \\
{[0.13]}\end{array}$ & 0.331 & $\begin{array}{c}0.877 \\
{[0.83]}\end{array}$ & $\begin{array}{c}8.67 \\
{[0.01]}\end{array}$ \\
\hline$\Delta i_{t-1}$ & $\begin{array}{l}0.352 \\
{[0.00]}\end{array}$ & & & \\
\hline$\Delta i_{t-2}$ & $\begin{array}{c}-0.010 \\
{[0.90]}\end{array}$ & & & \\
\hline$\Delta i_{t-3}$ & $\begin{array}{c}0.231 \\
{[0.01]}\end{array}$ & & & \\
\hline$\Delta i_{t}^{*}$ & $\begin{array}{r}-0.050 \\
{[0.85]}\end{array}$ & & & \\
\hline$\Delta U R R_{t-1}$ & $\begin{array}{l}-0.032 \\
{[0.31]}\end{array}$ & & & \\
\hline$\Delta U R R_{t-2}$ & $\begin{array}{r}-0.000 \\
{[0.98]}\end{array}$ & & & \\
\hline$\Delta U R R_{t-3}$ & $\begin{array}{c}0.053 \\
{[0.09]}\end{array}$ & & & \\
\hline$\Delta U R R_{t-4}$ & $\begin{array}{l}-0.001 \\
{[0.94]}\end{array}$ & & & \\
\hline$\Delta U R R_{t-5}$ & $\begin{array}{l}-0.073 \\
{[0.03]}\end{array}$ & & & \\
\hline Error-Correction-Term & $\begin{array}{l}-0.145 \\
{[0.00]}\end{array}$ & & & \\
\hline
\end{tabular}

Q-statistic refers to the test for serial correlation of the residuals of the model. Normality is the Jarque-Bera test for the normality of the residuals in the regression. P-values for all the test statistics are presented in brackets. 
APPENDIX A

Unit Root Tests for Selected Variables

\begin{tabular}{ccc}
\hline & ADF-GLS test statistic & Ng-Perron test statistic \\
\hline EMBI Spread & $-2.284(* *)$ & $-2.223(* *)$ \\
Argentina Pressure Index & $-4.628(* * *)$ & $-4.056(* *)$ \\
Chile Pressure Index & $-4.809(* * *)$ & $-4.037(* * *)$ \\
Colombia Pressure Index & $-7.817(* * *)$ & $-5.185(* *)$ \\
Mexico Pressure Index & $-5.353(* * *)$ & $-8.804(* * *)$ \\
Junk Bond Spread & $-2.198(* *)$ & $-2.205(* *)$ \\
Chile Output Gap & $-10.477(* *)$ & $-6.534(* * *)$ \\
Chile Inflation Gap & $-2.204(* *)$ & $-2.136(* *)$ \\
Chile Indexed Interest Rate & $-2.711(* * *)$ & $-2.598(* * *)$ \\
Chilean Country Risk & $-2.659(* * *)$ & $-2.496(* *)$ \\
Chile Terms of Trade & $-1.879(*)$ & $-1.720(*)$ \\
Chile Real Exchange Rate Gap & $-5.487(* * *)$ & $-5.419(* * *)$ \\
Colombia Output Gap & $-4.170(* * *)$ & $-5.117(* * *)$ \\
Colombia Inflation & $-2.413(* *)$ & $-2.546(* *)$ \\
Colombian Country Risk & -1.241 & -1.304 \\
Colombia Real Interest Rate & $-1.620(*)$ & $-1.664(*)$ \\
Colombia Real Exchange Rate & $-1.743(*)$ & $-9.615(* * *)$ \\
Gap & $-2.755(* * *)$ & $-2.847(* * *)$ \\
World Oil Prices & &
\end{tabular}

(**) Denotes significance at the $5 \%$ level and $(*)$ significance at the $10 \%$ level. Lag selection based on Schwartz information criterion.

Unit Root Tests for Residuals in Colombian VAR

\begin{tabular}{cll}
\hline & ADF-GLS & Ng-Perron \\
\hline EMBI Equation & $-8.134(* *)$ & $-5.090(* *)$ \\
Country Risk Equation & $-2.888(* *)$ & $-2.174(* *)$ \\
Output Gap Equation & $-2.549(* *)$ & $-1.958(*)$ \\
Inflation Gap & $-5.325(* *)$ & $-4.066(* * *)$ \\
Real Interest Rate & $-10.496(* * *)$ & $-5.267(* * *)$ \\
Real Exchange Rate & $-3.339(* * *)$ & $-2.699(* * *)$ \\
\hline
\end{tabular}

$(* * *)$ Denotes significance at the $1 \%$ level $(* *)$ Denotes significance at $5 \%$ level and $(*)$ significance at $10 \%$ level. Lag selection based on Schwartz information criterion. 


\section{Appendix B}

\section{Overview of Data \& Sources}

\begin{tabular}{|c|c|c|}
\hline Series & Description/Notes & Source \\
\hline $\begin{array}{l}\text { Domestic } \\
\text { Interest Rate }\end{array}$ & $\begin{array}{c}\text { Colombia: 90-day real deposit rate. Chile: exchange } \\
\text { rate indexed policy rate. }\end{array}$ & $\begin{array}{l}\text { Chilean Central Bank Website } \\
\text { (www.bcentral.cl) and Colombian } \\
\text { Central Bank Website } \\
\text { (www.banrep.gov.co). }\end{array}$ \\
\hline EMBI Spread & Global EMBI Spread. & $\begin{array}{l}\text { J.P. Morgan, obtained from } \\
\text { Thomson’s Datastream. }\end{array}$ \\
\hline Nominal & & IMF's International Financial \\
\hline $\begin{array}{l}\text { Exchange } \\
\text { Rates }\end{array}$ & & Statistics Database. \\
\hline $\begin{array}{l}\text { Rates } \\
\text { Reserves }\end{array}$ & & $\begin{array}{l}\text { IMF’s International Financial } \\
\text { Statistics Database. }\end{array}$ \\
\hline Output Gap & $\begin{array}{l}\text { Chile: difference between the log of the economic } \\
\text { activity index (IMACEC) and its trend and irregular } \\
\text { components obtained using a structural time series } \\
\text { model (estimated by Kalman filtering techniques). } \\
\text { Colombia: difference between the log of the industrial } \\
\text { production index and its trend, seasonal and irregular } \\
\text { components using a structural time series model. }\end{array}$ & $\begin{array}{l}\text { Author's calculations based on raw } \\
\text { data from respective Central Banks. }\end{array}$ \\
\hline Inflation Gap & Deviation of actual Inflation from Inflation target. & $\begin{array}{l}\text { Chile: The monthly inflation target } \\
\text { series provided by Gallego at al. } \\
\text { (2002). } \\
\text { Colombia: Central Bank Website } \\
\text { (www.banrep.gov.co). }\end{array}$ \\
\hline $\begin{array}{l}\text { Real Exchange } \\
\text { Rate }\end{array}$ & & $\begin{array}{l}\text { Chilean Central Bank Website } \\
\text { (www.bcentral.cl) and Colombian } \\
\text { Central Bank Website } \\
\text { (www.banrep.gov.co). }\end{array}$ \\
\hline $\begin{array}{l}\text { Real Exchange } \\
\text { Rate Gap }\end{array}$ & $\begin{array}{c}\text { Cyclical Component of Real Exchange Rate, obtained } \\
\text { by fitting a structural time series model (Kalman Filter) } \\
\text { to real exchange rate series. }\end{array}$ & Author's Calculations. \\
\hline $\begin{array}{l}\text { Country Risk } \\
\text { Premium }\end{array}$ & $\begin{array}{c}\text { Chile: premium on international bonds issued by } \\
\text { Chilean corporations. Colombia: Series constructed } \\
\text { using spread of Colombian bonds in international } \\
\text { markets over US T-bills. Updated using EMBI+ until } \\
2002\end{array}$ & $\begin{array}{l}\text { Central Bank of Chile, Rincon \& } \\
\text { Villar (2000) \& J.P. Morgan, } \\
\text { obtained from Thomson’s } \\
\text { Datastream. }\end{array}$ \\
\hline $\begin{array}{l}\text { Terms of } \\
\text { Trade }\end{array}$ & & $\begin{array}{l}\text { Bennett \& Valdes (2001) \& } \\
\text { Colombian Central Bank Website } \\
\text { (www.banrep.gov.co). }\end{array}$ \\
\hline $\begin{array}{l}\text { Junk Bond } \\
\text { Spread }\end{array}$ & $\begin{array}{l}\text { Difference in Yields between US High-Yield Bonds } \\
\text { and } 10 \text {-Year US Treasury Bonds. A number of } \\
\text { different High-Yield indexes where used such as } \\
\text { Master II (H0A0) and High Yield } 175 \text { (X0A0) }\end{array}$ & $\begin{array}{l}\text { Merrill Lynch, obtained from } \\
\text { Thomson’s Datastream. }\end{array}$ \\
\hline $\begin{array}{l}\text { World Oil } \\
\text { Price Index } \\
\text { International } \\
\text { Interest Rate } \\
\end{array}$ & 90-day Libor interest rate (in real terms) & $\begin{array}{l}\text { IMF's International Financial } \\
\text { Statistics Database. } \\
\text { IMF's International Financial } \\
\text { Statistics Database. } \\
\end{array}$ \\
\hline
\end{tabular}




\section{Appendix C \\ Calculation of the Tax Equivalent}

The vast majority of the literature adopts a "naïve" measure of this tax, which is constructed by combining an arbitrage condition and the uncovered interest parity equation. Consider the case where the maturity of the loan (capital inflow) $k$ is larger than the holding period of the deposit requirement $(h)$. Assuming that the exchange rate is fixed, the uncovered interest parity would take the form:

$$
(1+i)=\left(1+i^{*}\right)+\delta
$$

Where $i$ is the domestic interest rate, $i^{*}$ is the international interest rate and $\delta$ is the tax equivalent of the reserve requirement. The following arbitrage equation is also used:

$$
(1-u)(1+i)^{k}+u\left(1+E\left[\max \left(i, i^{*}\right)\right]\right)^{k-h}=\left(1+i^{*}\right)^{k}
$$

where $u$ is the unremunerated reserve requirement. The above expression simply states that the return from investing in Chile (considering the reserve requirements) has to be equal to the return obtained from investing abroad, i.e. the international interest rate (opportunity cost). Using the UIP condition to substitute for domestic interest rates and using the approximation that $(1+j)^{x} \cong(1+x j)$ for a small $j$, we can derive the usual naïve equation for the tax equivalent:

$\delta=\frac{u}{(1-u)} \frac{h}{k} i^{*}$

Note that the tax-equivalent is inversely related to the maturity of the capital inflow $(k)$, i.e. it falls more heavily on short-term capital inflows. This widely used measure of the tax equivalent of the reserve requirements has significant limitations. It does not take the country risk premium into account and does not consider variations in the exchange rate. In our analysis, we will adopt a measure of the tax-equivalent cost that incorporates those factors. Firstly, we will consider the case where the holding period of the deposit $(h)$ is equal to the maturity of the loan $(k)$. The UIP condition at present is given by:

$(1+i)=\left(1+i^{*}\right)(1+\lambda)\left(1+\Delta S^{e}\right)(1+\delta)$

where $\lambda$ is the country risk premium and $\Delta S^{\mathrm{e}}$ is the expected change in the exchange rate. The arbitrage condition is given by:

$\left[\left(1+i^{*}\right)(1+\lambda)\left(1+\Delta S^{e}\right)\right]^{k}=(1-u)(1+i)^{k}+u\left(1+\Delta S^{e}\right)^{h}$

where the term of the left-hand side is the opportunity cost of the investment decision (foreign interest rate plus country and currency risk), the first term on the right-hand side represents the returns on the amount actually invested (i.e. minus the reserve requirements) and the second term represents possible capital gains (or losses) from changes in the exchange rate. By manipulating those two equations we can obtain the following result:

$$
(1+\delta)=\frac{1}{\left(1+i^{*}\right)(1+\lambda)\left(1+\Delta S^{e}\right)}\left\{\frac{1}{1-u}\left[\left[\left(1+i^{*}\right)(1+\lambda)\left(1+\Delta S^{e}\right)\right]^{k}-u\left(1+\Delta S^{e}\right)^{h}\right]^{\frac{1}{k}}\right.
$$

Note that the same formula is valid for the case when the holding period of the deposit requirement is larger than the maturity of the loan, i.e. the case where $h>k$. This occurs because the arbitrage condition is very similar to the one outlined above, more specifically: 
$\left[\left(1+i^{*}\right)(1+\lambda)\left(1+\Delta S^{e}\right)\right]^{h}=(1-u)(1+i)^{k}+u\left(1+\Delta S^{e}\right)^{h}$

By manipulating this expression we obtain:

$$
(1+\delta)=\frac{1}{\left(1+i^{*}\right)(1+\lambda)\left(1+\Delta S^{e}\right)}\left\{\frac{1}{1-u}\left[\left[\left(1+i^{*}\right)(1+\lambda)\left(1+\Delta S^{e}\right)\right]^{h}-u\left(1+\Delta S^{e}\right)^{h}\right]\right\}^{\frac{1}{k}}
$$

Now we will proceed to calculating the tax equivalent when $h<k$ i.e. when the maturity of the investment is larger than the holding period of the reserve requirement. If we assume that the proceeds of the deposit requirement are reinvested abroad, the arbitrage condition becomes:

$$
\left[\left(1+i^{*}\right)(1+\lambda)\left(1+\Delta S^{e}\right)\right]^{k}=(1-u)(1+i)^{k}+u\left[\left(1+\Delta S^{e}\right)^{h}\left(1+i^{*}\right)^{k-h}\right]
$$

By manipulating this we obtain:

$$
(1+\delta)=\frac{1}{\left(1+i^{*}\right)(1+\lambda)\left(1+\Delta S^{e}\right)}\left\{\frac{1}{1-u}\left[\left[\left(1+i^{*}\right)(1+\lambda)\left(1+\Delta S^{e}\right)\right]^{k}-u\left[\left(1+\Delta S^{e}\right)^{h}\left(1+i^{*}\right)^{k-h}\right]\right]\right\}^{\frac{1}{k}}
$$

Evidently, those measures only constitute a proxy for the costs of the reserve requirements and depend on a certain number of restrictive assumptions. In the empirical implementations, we decided to use an average of the tax equivalent variable for different maturities and we experimented with different measures for the expected rate of exchange rate depreciation (or appreciation).

\footnotetext{
${ }^{\mathrm{i}}$ Those taxes are asymmetric in the sense that they fall more heavily on short-term capital inflows and did not apply to all capital flows (trade credits were usually exempt).

ii Original Sin is a term coined by Eichengreen and Hausman (1999) that essentially refers to the inability of developing countries to issue debt abroad in their own currency.

${ }^{\text {iii }}$ Chilean securities are not included in the EMBI index and Colombian ones were only included after 1998. In any case, the VAR methodology would be able to tackle the possible endogeneity problems that might arise.

${ }^{\text {iv }}$ Although Sims, Stock \& Watson (1990) prove that coefficients are consistently estimated independently of the order of integration.

"Throughout this paper a "significant" impulse response for each month following a shock means that the interval defined by the error bands does not contain the value zero. Note that error bands were calculated using Monte Carlo simulations (1000 repetitions).

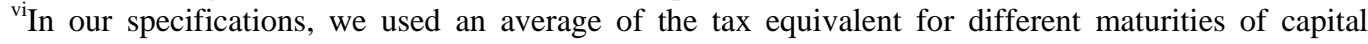
inflows.

vii One of the reasons why we did not extend our sample beyond December 2000 is that the inclusion of the 1999 dummy variable would change the asymptotic results of the tests, if the fraction of the sample during which the dummy is different from zero does not go to zero as the sample size increases (see Pesaran et al, 2001, p.307).

viii The test statistic is 1.83, which is below the critical bounds both at the $5 \%$ level and at the $10 \%$ level.

${ }^{\text {ix }}$ We used real (ex post) interest rates in this case to facilitate the comparison with the Chilean experience and eliminate the noise created by volatile inflation.
} 